\title{
PENGEMBANGAN MODUL ENGLISH IN ANALYZER DALAM PENINGKATAN KEMAMPUAN BERBAHASA INGGRIS BAGI MAHASISWA ANALIS KESEHATAN
}

\author{
Nova Mustika ${ }^{1}$ Anggun Sophia ${ }^{2}$ \\ STIKes Perintis Padang, Sumatera Barat, Indonesia ${ }^{12}$ \\ e-mail : nova_mustika1188@yahoo.com ${ }^{1}$, ${\text { anggunshophia@gmail.com }{ }^{2}}^{2}$
}

\begin{abstract}
Abstrak
Penelitian ini bertujuan mengembangkan modul English in Analyzer dalam peningkatan kemampuan berbahasa Inggris bagi mahasiswa analis kesehatan yang valid. Jenis penelitian yang digunakan adalah penelitian dan pengembangan atau Research and Development (R\&D), yaitu penelitian yang menghasilkan produk tertentu. Model pengembangan yang digunakan dalam penelitian ini adalah model 4 D yaitu Define, design, develop, disseminate. Instrumen penelitian yang digunakan berupa angket yang terdiri dari lembar validitas tes hasil belajar bahasa Inggris. Modul English in Analyzer inidivalidasi oleh 3 orang validator terdiri dari 1 orang Dosen bergelar Doktor Bahasa Inggris, 1 Orang dosen Bahasa Inggris STIKes Perintis Padang, dan 1 orang Dosen Analis Kesehatan STIKes Perintis. Hasil analisis lembaran validitas, menunjukkan skor rata-rata momen kappa $(\mathrm{k})$ adalah 0,79 . Skor ini jika diinterpretasikan pada kategori momen kappa maka kategori validitas Tinggi. Modul yang berhasil dikembangkan valid digunakan untuk pembelajaran Bahasa Inggris Bagi Mahasiswa Analis Kesehatan.
\end{abstract}

Kata Kunci: Modul, English in Analyzer, Kemampuan Berbahasa Inggris

\begin{abstract}
This research aims to develop English in Analyzer module in improving English language skills for health analyst students that valid. This type of research used is research and development or Research and Development $(R \& D)$, which is research that produces certain products. The development model used in this study is the 4 D model, namely Define, design, develop, disseminate. The research instrument used in the form of a questionnaire consisting of sheets of the validity of English learning outcomes tests. This English in Analyzer module is validated by 3 validators consisting of 1 Lecturer with an English Doctor's Degree, 1 English Lecturer at the STIKes Perintis Padang and 1 Health Analyst Lecturer at the STIKes Perintis Padang. The results of the validity sheet analysis showed the average kappa moment $(k)$ score was 0.79 . This score if interpreted in the kappa moment category then the category of High validity. Modules that have been developed are valid for use in learning English for Health Analyst Students.
\end{abstract}

Keywords: Module, English in Analyzer, English Language Ability

@Edukasi: Jurnal Ilmu Pendidikan FIP UPTT 2019

$\triangle$ Corresponding author :

Address :

Email : nova_mustika1188@yahoo.com

Phone
ISSN 2656-8063 (Media Cetak) ISSN 2656-8071 (Media Online) 
108 Pengembangan Modul English in Analyzer Dalam Peningkatan Kemampuan Berbahasa Inggris Bagi Mahasiswa Analisis Kesehatan- Nova Mustika, Anggun Sophia

\section{PENDAHULUAN}

Bahasa Inggris memiliki peran yang sangat penting dalam era globalisasi saat sekarang ini. Bahasa Inggris sangat diperlukan baik dalam menguasai teknologi komunikasi maupun dalam berinteraksi secara langsung. Sebagai sarana komunikasi global, bahasa Inggris memiliki peran yang sangat strategis dalam mencapai keberhasilan sebuah karir. Oleh karena itu dunia pendidikan khususnya perguruan tinggi kesehatan berlomba-lomba untuk mengintegrasikan kemampuan akademik para mahasiswanya dengan kemampuan berbahasa Inggris.

STIKes Perintis sebagai salah satu perguruan tinggi kesehatan dengan memiliki program salah satu studi analis kesehatan telah menempatkan matakuliah bahasa Inggris sebagai keterampilan yang harus dikuasai oleh mahasiswanya. Pada kenyataan saat ini masih banyak dari mahasiswa belum mencapai nilai Kriteria Ketuntasan Minimal (KKM) yang menjadi indikator rendahnya kemampuan berbahasa Inggris mahasiswa analis kesehatan. Belum lagi kurang tepatnya penerapan metode pembelajaran juga menjadi salah satu faktor penyebab hal tersebut, selain faktor lain misalnya kurangnya kesempatan mengulang materi karena terbatasnya waktu tatap muka serta terbatasnya pelayanan umpan balik agar mahasiswa analis kesehatan mengetahui kebutuhan mereka. Sementara itu kondisi ideal dari hasil dari sebuah proses pembelajaran adalah efektifitas, efisiensi dan memiliki daya tarik yang baik. Tujuan yang hendak dicapai dari penelitian ini berdasarkan rumusan masalah yang sudah dirumuskan yaitu: a) mengembangkan modul pembelajaran English in Analyzer terhadap mahasiswa Analis Kesehatan tingkat 1 STIKes Perintis Padang untuk belajar mandiri dalam rangka mengatasi kendala terbatasnya waktu untuk tatap muka dengan dosen. b) mengungkapkan validitas, modul pembelajaran English in Analyzer terhadap mahasiswa Analis Kesehatan tingkat 1 STIKes Perintis Padang. Urgensi penelitian ini adalah Spesifikasi Produk Modul yang ada memfasilitasi mahasiswa belajar mandiri, Modul yang dikembangkan mengikuti pola mahasiswa belajar mandiri.

Peraturan Pemerintah Nomor 19 Tahun 2005 tentang Standar Nasional Pendidikan, Bab VII Standar Sarana dan Prasarana, pasal 42 menegaskan bahwa : Setiap satuan pendidikan wajib memiliki sarana yang meliputi perabot, peralatan pendidikan, media pendidikan, buku/modul dan sumber belajar lainnya, bahan habis pakai, serta perlengkapan lain yang diperlukan untuk menunjang proses pembelajaran yang teratur dan berkelanjutan, Setiap satuan pendidikan wajib memiliki prasarana yang meliputi lahan, ruang kelas, ruang pimpinan satuan pendidikan, ruang pendidik, ruang tata usaha, ruang perpustakaan, ruanglaboratorium, ruang bengkel kerja, ruang unit produksi, ruang kantin, instalasi daya dan jasa, tempat olahraga, tempat beribadah, tempat bermain, tempat berkreasi, dan ruang/ tempat lain yang diperlukan untuk menunjang proses pembelajaran yang teratur dan berkelanjutan.

Prinsip Belajar Mandiri paling sedikit ada dua hal untuk dapat melaksanakan belajar mandiri, yaitu : 1) digunakannya program belajar yang mengandung petunjuk untuk belajar sendiri oleh peserta didik dengan 
109 Pengembangan Modul English in Analyzer Dalam Peningkatan Kemampuan Berbahasa Inggris Bagi Mahasiswa Analisis Kesehatan- Nova Mustika, Anggun Sophia

bantuan guru yang minimal, dan 2) melibatkan siswa dalam perencanaan dan pelaksanaan kegiatan.

Modul Pembelajaran system pembelajaran mandiri memang menuntut para peserta didiknya untuk dapat melakukan kegiatan belajar secara mandiri. Proses pembelajaran akan lebih efektif dan efisien jika dibantu dengan bahan ajar. Modul merupakan bahan ajar cetak yang dirancang untuk dapat dipelajari secara mandiri. Modul adalah suatu cara pengorganisasian materi pelajaran yang memperhatikan fungsi pendidikan.

Tujuan disusunnya modul ialah agar peserta dapat menguasai kompetensi yang diajarkan dalam diklat atau kegiatan pembelajaran dengan sebaik-baiknya. Bagi dosen, modul juga menjadi acuan dalam menyajikan dan memberikan materi selama perkuliahan atau kegiatan pembelajaran berlangsung.

Fungsi modul ialah sebagai bahan belajar yang digunakan dalam kegiatan pembelajaran mahasiswa. Dengan modul mahasiswa dapat belajar lebih terarah dan sistematis. Mahasiswa diharapkan dapat menguasai kompetesi yang dituntut oleh kegiatan pembelajaran yang diikutinya. Modul juga diharapkan memberikan petunjuk belajar bagi peserta selama mengikuti perkuliahan. Modul dapat dikembangkan dengan berbagai cara antara lain melalui adaptasi, kompilasi, dan menulis sendiri.

Bahasa Inggris adalah salah satu bahasa asing yang dianggap penting yang harus dikuasai oleh Bangsa Indonesia karena bahasa Inggris memiliki kedudukan yang sangat strategis, yaitu selain sebagai alat komunikasi juga sebagai bahasa pergaulan antar bangsa. Selain itu, bahasa Inggris juga merupakan bahasa asing pertama yang dianggap penting untuk tujuan pengaksesan informasi, penyerapan dan pengembangan ilmu pengetahuan, teknologi, dan seni budaya.

Dalam kaitannya dengan bahasa asing mengemukakan adanya istilah bahasa target yang merupakan bahasa yang sedang dipelajari dan ingin dikuasai. Wujud bahasa target dapat berupa bahasa ibu (bahasa pertama (B1), bahasa kedua (B2), maupun bahasa asing (BA). Pengertian bahasa kedua tidak sama dengan bahasa bahasa asing. Di Indonesia misalnya, pertama kali pembelajar belajar bahasa pertama (bahasa daerah), kemudian belajar bahasa kedua (bahasa Indonesia).

Kemampuan berbahasa pada hakikatnya adalah ketrampilan, bukan sekedar pengetahuan. Ketrampilan berbahasa itu ada empat macam: mendengarkan (listening), berbicara (speaking), membaca (reading), dan menulis (writing). Untuk setiap ketrampilan itu diperlukan komponen bahasa yang berupa pengetahuan tentang kosakata, tata bahasa, cara pengucapan (untuk bahasa lisan), dan system ejaan (untuk bahasa tulis).

\section{METODE PENELITIAN}

Penelitian ini menggunakan pendekatan Reasearch and Development (R\&D) atau dengan kata lain penelitian ini akan berfokus pada penelitian terhadap analisa kebutuhan mahasiswa analis kesehatan dalam upaya meningkatkan kemampuan mereka 
110 Pengembangan Modul English in Analyzer Dalam Peningkatan Kemampuan Berbahasa Inggris Bagi Mahasiswa Analisis Kesehatan- Nova Mustika, Anggun Sophia

dalam penguasaan bahasa Inggris dan juga dalam penelitian ini penulis juga akan berfokus pada upaya mengembangkan sebuah modul pembelajaran sebagai sarana yang dapat membantu mahasiswa analis kesehatan dalam menguasai bahasa Inggris.

Prosedur pengembangan yang dilakukan pada penelitian ini adalah tahap Define (pendefinisian), Design (perancangan), Develop (pengembangan) dan Disseminate (penyebaran) namun pada tahap disseminate (penyebaran). Prosedur pengembangan yang dilakukan merujuk kepada model pengembangan perangkat pembelajaran 4-D yang digambarkan sebagai berikut.

Subjek untuk uji coba modul pembelajaran dalam penelitian ini adalah mahasiswa Analis Kesehatan STIKes Perintis Padang yang mengambil mata kuliah Bahasa Inggris.

Jenis data pada penelitian ini adalah data sekunder dan data primer. Data sekunder berupa data jumlah mahasiswa analis kesehatan STIKes Perintis Padang, yang mengikuti mata kuliah Bahasa Inggris, sedangkan untuk data primer yaitu diperoleh dari pendapat pakar mengenai produk modul yang akan dikembangkan.

Teknik pengumpulan data digunakan dalam rangka memperoleh informasi tentang need assessment dan pengelolaan dalam pemecahan masalah dengan menggunakan teknik wawancara, observasi dan angket. Teknik analisis data yang digunakan dalam penelitian ini adalah teknik analisis data deskriptif, yaitu dengan mendeskripsikan kevali dan penggunaan modul pembelajaran pada mata kuliah praktikum Bahasa Inggris.

\section{HASIL DAN PEMBAHASAN PENELITIAN}

Modul English in Analyzer bertujuan untuk meningkatkan hasil belajar dan motivasi mahasiswa STIKes Perintis Padang. Modul yang dikembangkan sesuai dengan materi pada mata kuliah Bahasa Inggris. Pengembangan Modul ini dilakukan dengan model penelitian dan pengembangan 4D, dimana tahap pengembangan yaitu: a) Tahap pendefinisian (Define), berupa analisis awal kebutuhan terhadap modul yang akan dikembangkan. (b) Tahap Perancangan (Design), berupa rancangan Modul praktikum pada Mata kuliah Bahasa Inggris c) Tahap Pengembangan (Develop) berupa uji validasi materi dan format modul, uji praktikalitas, dan efektivitas terhadap modul English in Analyzer, dan (d) Tahap Penyebaran (Desseminate) berupa tahap penyebarluasan modul yang telah dikembangkan.

Modul English in Analyzer ini telah melalui tahap uji coba validitas. Pada uji coba validitas dilakukan dengan cara meminta pendapat kepada validator melalui angket. Dari uji coba validitas yang dilakukan setelah melalui beberapa kali revisi didapatkan hasil Modul pembelajaran pada Bahasa Inggris ini valid digunakan sebagai salah satu media pembelajaran.

Review oleh Ahli Materi Pelajaran I, penilaian ahli materi terhadap isi Modul English in Analyzer penulis jelaskan dalam gambar 1. Berdasarkan penilaian ahli materi pembelajaran dapat diketahui bahwa modul English in analyzer dari sisi kelayakan isi 
111 Pengembangan Modul English in Analyzer Dalam Peningkatan Kemampuan Berbahasa Inggris Bagi Mahasiswa Analisis Kesehatan- Nova Mustika, Anggun Sophia

mendapatkan nilai rata-rata 4,8 dengan skala sangat baik/sangat sesuai. Dari sisi komponen bahasa mendapatkan nilai rata-rata 4,8 dengan skala sangat baik/sangat sesuai. Dari sisi komponen penyajian mendapatkan nilai ratarata 4,8 dengan skala sangat baik/sangat sesuai. Dari segi komponen kegrafisan mendapatkan nilai rata-rata 4,6 dengan skala sangat baik/sangat sesuai. Saran yang diperoleh dari ahli materi adalah untuk konteks percakapan dan bacaan lebih ditonjolkan dalam suasana dunia medis, misalkan percakapan di ruang praktek dokter, di rumah sakit, atau klinik pengobatan.

Review oleh Ahli Materi II Penilaian ahli media terhadap isi Modul English in Analyzer penulis jelaskan dalam gambar 1 . Berdasarkan penilaian ahli materi pembelajaran 2 dapat diketahui bahwa modul English in analyzer dari sisi kelayakan isi mendapatkan nilai rata-rata 5 dengan skala sangat baik/sangat sesuai. Dari sisi komponen bahasa mendapatkan nilai rata-rata 4,8 dengan skala sangat baik/sangat sesuai. Dari sisi komponen penyajian mendapatkan nilai ratarata 4,5 dengan skala sangat baik/sangat sesuai. Dari segi komponen kegrafisan mendapatkan nilai rata-rata 4,8 dengan skala sangat baik/sangat sesuai. Hanya saja alangkah baiknya jika warna yang dipergunakan tidak hitam putih agar lebih bervariasi.

Review oleh Dosen Analis Kesehatan penilaian ahli Dosen terhadap isi Modul English in Analyzer penulis jelaskan dalam gambar 1. Berdasarkan penilaian ahli dosen pembelajaran dapat diketahui bahwa modul English in analyzer dari sisi kelayakan isi mendapatkan nilai rata-rata 4 dengan skala baik/ sesuai. Dari sisi komponen bahasa mendapatkan nilai rata-rata 4,6 dengan skala sangat baik/sangat sesuai. Dari sisi komponen penyajian mendapatkan nilai rata-rata 4,2 dengan skala baik/ sesuai. Dari segi komponen kegrafisan mendapatkan nilai rata-rata 4,5 dengan skala sangat baik/sangat sesuai. Sarannya adalah agar menambahkan beberapa artikel dan kalimat yang terkaitan dengan dunia analis kesehatan.

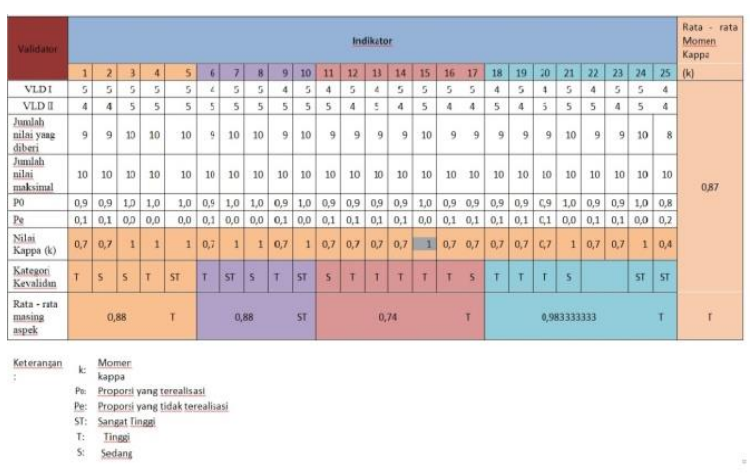

Gambar 1. Rangkuman Hasil Validasi

\section{KESIMPULAN}

Berdasarkan hasil penelitian pengembangan modul yang telah dilakukan, maka diperoleh kesimpulan; 1) telah berhasil dikembangkan sebuah modul English in Analyzer yang telah melalui uji validitas. 2) perancangan dan pembuatan modul English in Analyzer telah melalui tahap uji validitas dan hasil tahap uji validitas ini menyatakan bahwa modul English in Analyzer ini sudah valid.

\section{DAFTAR PUSTAKA}

Aflah, M. N., \&Rahmani, E. F. (2018). Analisa Kebutuhan. Jurnal Pendidikan Bahasa, 6(1), 55-62.

Chaer, A. (2009). Pengantar Semantik Bahasa Indonesia. Jakarta: Rineka Cipta. 
112 Pengembangan Modul English in Analyzer Dalam Peningkatan Kemampuan Berbahasa Inggris Bagi Mahasiswa Analisis Kesehatan- Nova Mustika, Anggun Sophia

Ditjen. PMPTK. (2008). Penulisan Modul. (D.

P. M. P. T. Kejuruan., Ed.). Jakarta.

Fallis, A. . (2013). 済無No Title No Title. Journal of Chemical Information and Modeling (Vol. 53). https://doi.org/10.1017/CBO97811074 $\underline{15324.004 .}$.

Kebudayaan, K. P. \&. (2016). Pedoman Revisi Modul. Medan: Pusat Pengembangan dan Pemberdayaan Pendidikan dan Tenaga Kependidikan.

Miarso, Y. hadi. (2004). Menyemai Benih Teknologi Pendidikan. Jakarta: Kencana.

Santayasa, W. (2009). Metode Penelitian Pengembangan dan Teori Pengembangan Modul. Universitas Pendidikan Ganesa.

Trianto. (2012). Mendesain Model Pembelajaran Inovatif-Progresif. Jakarta: Kencana Predana Media Group. 